\title{
Streptococcus mutans and Streptococcus sobrinus detection by Polymerase Chain Reaction and their relation to dental caries in 12 and 15 year-old schoolchildren in Valencia (Spain)
}

\author{
Mateo Sánchez-Acedo ${ }^{1}$, José-María Montiel-Company ${ }^{2}$, Francisco Dasí-Fernández ${ }^{3}$, José-Manuel Almerich- \\ Silla ${ }^{4}$

\footnotetext{
${ }^{1}$ Associate. Departament of Stomatology, University of Valencia, Spain

${ }^{2}$ Post-Doctoral Assistant lecturer. Departament of Stomatology, University of Valencia, Spain

${ }^{3} \mathrm{PhD}$. Fundación Investigación Hospital Clínico Universitario de Valencia/INCLIVA. Valencia, Spain

${ }^{4}$ Tenured Lecturer, Departament of Stomatology, University of Valencia, Spain
}

Correspondence:

Departament d'Estomatologia

Clínica Odontológica

Universitat de València

C/ Gascó Oliag 1

Valencia, 46010, Spain

jose.m.almerich@uv.es

Received: 26/11/2012

Accepted: 21/02/2013

\begin{abstract}
Sánchez-Acedo M, Montiel-Company JM, Dasí-Fernández F, AlmerichSilla JM. Streptococcus mutans and Streptococcus sobrinus detection by Polymerase Chain Reaction and their relation to dental caries in 12 and 15 year-old schoolchildren in Valencia (Spain). Med Oral Patol Oral Cir Bucal. 2013 Nov 1;18 (6):e839-45.

http://www.medicinaoral.com/medoralfree01/v18i6/medoralv18i6p839.pdf
\end{abstract}

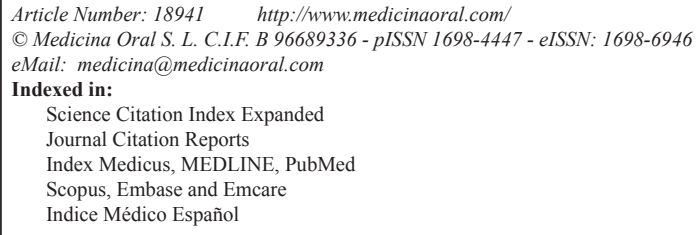

\begin{abstract}
A cross-sectional study was carried out to determine the prevalence of Streptococcus mutans and Streptococcus sobrinus and the association of the two in a random sample $(\mathrm{n}=614)$ of the child population of the region of Valencia (Spain). Saliva samples were analyzed by the quantitative polymerase chain reaction (PCR) method to study the relation of these bacteria to caries prevalence and the DMFT index.

The prevalence of $S$. mutans was $35.4 \%$ at age 12 and $22.9 \%$ at age 15 , that of $S$. sobrinus $18.9 \%$ and $8.4 \%$ and that of the S. mutans-S. sobrinus association $18.2 \%$ and $6.8 \%$ respectively. At both 12 and 15 years of age, the caries prevalence rates were lower in the Streptococcus-free group of children (37.6\% and $48.5 \%$ respectively) and higher in the S.mutans-only group $(67.3 \%$ and $74.0 \%)$. At the age of 12 , the DMFT index was significantly higher in the mutans-only carriers (2.1) than in the Streptococcus-free and S. mutans-S. sobrinus association groups (both $0.9)$. At the age of 15 , the DMFT index was significantly higher in the S. mutans-S. sobrinus association (3.71) and mutans-only (3.1) carrier groups than in the Streptococcus-free group (1.4).

Determination of $S$. mutans and $S$. sobrinus by real-time quantitative PCR can provide valuable information for caries risk assessment in epidemiological studies.
\end{abstract}

Key words: Streptococcus mutans, Streptococcus sobrinus, polymerase chain reaction, dental caries, crosssectional studies. 


\section{Introduction}

Dental caries presents a multifactorial aetiology, as environmental factors, food and hygiene habits and individual genetic susceptibility all play an important role in the development of this disease (1).

Streptococcus mutans and Streptococcus sobrinus are strongly implicated in the onset of human dental caries. Numerous studies have shown the association of $S$. mutans and S. sobrinus with higher caries levels (2-4) and several studies have found that $S$. sobrinus prevalence is more strongly associated with high caries activity than that of $S$. mutans (5-6). It is considered that determination of these two species in early childhood could be important for diagnosing and preventing dental caries. Some authors (7-8) have developed PCR methods to detect $S$. mutans in samples of dental plaque. To facilitate biological sample collection for epidemiological studies, it has been developed a PCR method to detect $S$. mutans and $S$. sobrinus in saliva, using specific primers for the genes that encode glucosyltransferase ( $\mathrm{gtfB}$ in $S$. mutans and gtfI in $S$. sobrinus), which can be used to assess the prevalence of these organisms in epidemiological studies (9).

Based on a strong correlation between microorganism counts in saliva and plaque, $S$. mutans determination in saliva has been suggested as a suitable method for identifying patients at high risk of dental caries (10). As saliva is continuously in contact with all the teeth, it provides a better reflection of the colonization of mutans streptococci on all dentition (11).

The objectives of this study were to determine the prevalence of $S$. mutans and $S$. sobrinus and of the association of $S$. mutans and $S$. sobrinus in the 12 and 15 year-old child population of the region of Valencia (Spain), employing a quantitative PCR method in saliva samples, and to examine the relation of these bacteria to caries prevalence and the DMFT index.

\section{Material and Methods}

-Study group

A cross-sectional epidemiological study was conducted in a random sample of a child population of 12 and 15 years of age in the Valencia region of Spain. The child population of the Valencia region comprises 45,000 children aged 12 years and a similar number aged 15 years, who attend more than 1,500 primary and secondary schools in the region. Random sampling of clusters (classes in schools) was conducted, resulting in the selection of classes in 27 schools for observations of 12year-old children and classes in 20 schools for observations of 15-year-old children (12).

Of the population examined, saliva samples were only collected from children whose parents signed an informed consent form, resulting in a final sample size for this study of 303 children out of the 478 examined at the age of 12 and 311 out of the 401 examined at the age of 15 years.

-Clinical examination

To ensure the reliability of the measurements, caries diagnosis calibration of the 6 dentists recruited for the study was carried out during the weeks prior to commencement of the study. The three dentists with the highest agreement, assessed using the Kappa index with a gold standard-experienced examiner, were appointed as examiners. The Kappa values for the gold standard examiner comparisons were $0.91,0.86$, and 0.85 , respectively, for the three examiners.

The clinical examinations were performed in the schools, with the child sitting on a chair, using a portable $60 \mathrm{~W}$ white-blue spectrum lamp as the source of illumination. No more than 25 children were examined during a session to avoid the effects of visual tiredness. The examination instruments employed were a WHO type periodontal probe and a no. 5 plain mouth mirror. Each examination team was provided with 35 sets of sterilized probes and mirrors, each in a sealed bag, placed in a portable plastic container. The field work was carried out during November and December 2004. -Written questionnaire

To collect information on oral health-related behaviours, the children were asked to complete a written questionnaire. The questionnaire consisted of multiple choice test questions which had already been used and validated in other studies in Spain (12). Included in the questions were requests for information on tooth brushing frequency and on the frequency of intake of cariogenic foods. Fluoride rinses carried out once a week at school was also recorded.

-Measurements

The WHO caries criteria (13) were employed for diagnosing and coding all the tooth examined. Two outcome variables were considered: the DMFT count and caries prevalence (DMFT $>0$ ) at the age of 12 and 15.

The fulfillment of the school-based fluoride mouth-rinsing programs was recorded as high if weekly schoolbased fluoride rinsing had been carried out for at least one academic year prior to the examinations. Otherwise it was considered low.

The intake of cariogenic foods was considered high if cariogenic foods (foods with a high refined sugar content) were eaten between meals every day or almost every day. Otherwise the cariogenic food intake was considered low.

Finally, the daily tooth brushing habit was recorded as appropriate if the child reported brushing his or her teeth at least once a day, otherwise the daily tooth brushing habit was considered inappropriate.

-Saliva Samples

The saliva was collected with a no.50 sterile paper point, held in forceps with sterile beaks and placed on 
the tip of the child's tongue for 1 minute until soaked with saliva. Each point was then transferred with the forceps to a sterile Eppendorf tube. The tubes were transported in a portable refrigerator to a freezer where they were stored at $-80^{\circ} \mathrm{C}$. None of the journey times exceeded 3-4 hours.

-DNA isolation of S. mutans and $\mathrm{S}$. sobrinus from saliva samples

The isolation and purification of the genomic DNA was carried out with the ChargeSwitch Forensic DNA Purification kit (Invitrogen). (Invitrogen Corporation 1600 Faraday Avenue Carlsbad, California 92008).

-Quantitative PCR

Calculation of copy number

Standard curves were obtained using the bacterial strains S. mutans (CCUG 11877T, serotype c; Clarke 1924-AL) and S. sobrinus (CCUG 27507, serotype d; Coykendall 1983-VP). The bacterial strains were cultured on blood agar plates and then subjected to 0.5 McFarland suspension (equivalent to $1.5 \times 10^{8} \mathrm{CFU} /$ $\mathrm{ml}$ ). Serial dilutions were performed to obtain bacterial suspensions from $1 \times 10^{0}$ to $1 \times 10^{7} \mathrm{CFU}$. Quantitative detection of $S$. mutans and $S$. sobrinus was performed using the TaqMan assay (14). Briefly, gene-specific primer pairs (200 nmM each) and probes (250 nM) for $S$. mutans and S. sobrinus were used with $1 \mathrm{X}$ TaqMan Universal PCR Master Mix (Applied Biosystems) and 5 $\mu \mathrm{l}$ of isolated bacterial DNA in $20 \mu \mathrm{l}$ reaction volume. The PCR conditions were $10 \mathrm{~min}$ at $95^{\circ} \mathrm{C}$ for enzyme activation, followed by 45 two-step cycles $\left(15 \mathrm{sec} 95^{\circ} \mathrm{C}\right.$; $1 \mathrm{~min}$ at $58^{\circ} \mathrm{C}$ ). Detection was performed using the ABI PRISM 7900 Sequence Detection System. Standard curves for each organism were obtained from the amplification of genomic DNA from samples containing $1.0 \mathrm{x}$ 100 to $1.0 \times 10^{7} \mathrm{CFU}$. Each sample was analyzed in triplicate and the $\mathrm{Ct}$ value of each sample was converted to quantity of $S$. mutans and $S$. sobrinus using the standard curves measured in the same experiment. The linearity and sensitivity of the assay was also determined from these standard curves by qPCR.

The detection and quantification was linear over a range from $1.0 \times 10^{2}$ and $1.0 \times 10^{7} \mathrm{CFU}$ per reaction mixture for both $S$. mutans and $S$. sobrinus. This assay was used to determine the numbers of S. mutans and S. sobrinus from 303 children aged 12 and 311 aged 15 years.

-Statistical analysis

The data were analysed with the SPSS 19.0 statistics application. The samples were divided into four Streptococcus carrier status groups: free of Streptococci, carrying only $S$. mutans, carrying only S. sobrinus, or carrying an association of $S$. mutans-S. sobrinus. A univariate analysis was performed to compare the mean DMFT values using the ANOVA test or Student's t test. A chi-square test was used for testing differences in caries prevalence. A logistic regression analysis was also performed with caries prevalence as the dependent variable and free of Streptococci, carrying only $S$. mutans, carrying only $S$. sobrinus, carrying an association of S. mutans-S. sobrinus, daily tooth brushing, intake of cariogenic food, fluoride rinsing and age as independent variables.

\section{Results}

In the 12-year-old group the mean DMFT was 1.13 (95\% confidence interval CI-95\% $0.94-1.32$ ) and the caries prevalence was $52.2 \%$. At the age of 15 , the results were DMFT 1.81 (CI-95\%: 1.53-2.009) and caries prevalence $54.3 \%$.

The Streptococcus mutans, S. sobrinus and $S$. mutans-S. sobrinus association prevalence data are shown in table 1. The prevalence of $S$. mutans was $35.4 \%$ at age 12 and $22.9 \%$ at age 15 , that of $S$. sobrinus $18.9 \%$ and $8.4 \%$ and that of the $S$. mutans-S. sobrinus association $18.2 \%$ and $6.8 \%$ respectively.

Table 1. Prevalence of Streptococci Mutans and Sobrinus.

\begin{tabular}{|c|c|c|c|}
\hline $\begin{array}{c}\text { Streptococcus carrier } \\
\text { status group }\end{array}$ & $\begin{array}{c}\text { Age 12 years } \\
\mathbf{N = 3 0 3} \% \\
\mathbf{( 9 5 \%} \mathbf{~ C I )}\end{array}$ & $\begin{array}{c}\text { Age 15 years } \\
\mathbf{N = 3 1 1} \% \\
\mathbf{( 9 5 \%} \mathbf{C I})\end{array}$ & $\begin{array}{c}\text { Both groups } \\
\mathbf{N = 6 1 4} \% \\
\mathbf{( 9 5 \%} \mathbf{C I})\end{array}$ \\
\hline $\begin{array}{c}\text { Free of } \text { Streptococci } \\
\text { Mutans and Sobrinus }\end{array}$ & $\begin{array}{c}64.0 \\
(58.5-69.2)\end{array}$ & $\begin{array}{c}75.6 \\
(70.5-80.0)\end{array}$ & $\begin{array}{c}69.9 \\
(66.6-73.4)\end{array}$ \\
\hline Only S. Mutans & 17.2 & 16.1 & 16.6 \\
& $(13.3-21.8)$ & $(12.4-20.6)$ & $(13.9-19.8)$ \\
\hline Only S. Sobrinus & 0.7 & 1.6 & 1.1 \\
& $(0.1-2.3)$ & $(0.6-3.7)$ & $(0.5-2.3)$ \\
\hline $\begin{array}{c}\text { S. } \text { Mutans-S. Sobrinus } \\
\text { association }\end{array}$ & 18.2 & 6.8 & 12.4 \\
& $(14.2-22.8)$ & $(4.4-10.1)$ & $(10.0-15.2)$ \\
\hline
\end{tabular}


The mean $S$. mutans level was $6.47 \times 10^{4} \mathrm{CFU} / \mathrm{ml}$ $\left(1.81 \times 10^{3}-1.28 \times 10^{5}\right)$ at 12 years of age $(n=303)$ and $2.11 \times 10^{4}\left(5.95 \times 10^{3}-3.63 \times 10^{4}\right)$ at 15 years $(n=311)$. The S. sobrinus levels were $1.44 \times 10^{4} \mathrm{CFU} / \mathrm{ml}\left(3.04 \times 10^{3}-2\right.$ $\left..56 \times 10^{4}\right)$ and $1.36 \times 10^{3} \mathrm{CFU} / \mathrm{ml}\left(0-2 \times 10^{3}\right)$ respectively. The different groups exhibit significant differences in caries prevalence and DMFT (Table 2). At both 12 and 15 years of age, the Streptococcus-free group of children had lower caries rates than the other groups and the S.mutans-only group presented the highest caries prevalence. Among the 12 year-olds, the DMFT score was significantly higher in the mutans-only group than in the Streptococcus-free and $S$. mutans-S. sobrinus association groups. Among the 15 year-olds, the DMFT score was significantly higher in the $S$. mutans-S. sobrinus association and mutans-only groups than in the Streptococcus-free group. In the sample as a whole, the caries prevalence and DMFT index were significantly higher in the mutans-only carriers than in the Streptococcus-free and $\mathrm{S}$. mutans-S. sobrinus association groups.

In table 3 Streptococcus-free group was higher and $\mathrm{S}$. mutans group lower in DMFT index scores $\leq 3$ than scores $>3$ at both 12 and 15 year-olds. Significant differences were exhibit between the four groups by DMFT index scores in both.

Table 4 shows the results of the multiple logistic regression analysis with caries prevalence as the dependent variable. Carrying only S. mutans, daily intake of cariogenic foods and age were significantly associated with caries prevalence in this sample.

Table 2. Streptococcus carrier status group in relation to caries prevalence and the DMFT index.

\begin{tabular}{|c|c|c|c|c|c|c|}
\hline \multirow[t]{2}{*}{$\begin{array}{l}\text { Streptococcus } \\
\text { status group }\end{array}$} & \multicolumn{2}{|c|}{$\begin{array}{l}\text { Age } 12 \text { years } \\
\qquad N=303\end{array}$} & \multicolumn{2}{|c|}{$\begin{array}{l}\text { Age } 15 \text { years } \\
\qquad N=311\end{array}$} & \multicolumn{2}{|c|}{$\begin{array}{l}\text { Both groups } \\
\quad \mathrm{N}=614\end{array}$} \\
\hline & $\begin{array}{c}\text { Prevalence of } \\
\text { caries* } \\
\text { DMFT >0\% } \\
(95 \% \text { CI })\end{array}$ & $\begin{array}{l}\text { DMFT* } \\
\text { Mean } \\
(95 \% \text { CI })\end{array}$ & $\begin{array}{c}\text { Prevalence of } \\
\text { caries* } \\
\text { DMFT >0 \% } \\
(95 \% \text { CI }\end{array}$ & $\begin{array}{c}\text { DMFT* } \\
\text { Mean } \\
(95 \% \text { CI })\end{array}$ & $\begin{array}{c}\text { Prevalence of } \\
\text { caries* } \\
\text { DMFT >0 \% } \\
(95 \% \text { CI }\end{array}$ & $\begin{array}{c}\text { DMFT* } \\
\text { Mean } \\
(95 \% \text { CI })\end{array}$ \\
\hline $\begin{array}{c}\text { Free of Streptococci } \\
\text { Mutans and Sobrinus }\end{array}$ & $\begin{array}{c}37.6 \\
(31.1-44.6)\end{array}$ & $\begin{array}{c}0.93 \\
(0.72-1.15)\end{array}$ & $\begin{array}{c}48.5 \\
(42.2-54.9)\end{array}$ & $\begin{array}{c}1.36 \\
(1.09-1.63)\end{array}$ & $\begin{array}{c}43.6 \\
(38.9-48.3)\end{array}$ & $\begin{array}{c}1.17 \\
(0.99-1.34)\end{array}$ \\
\hline Only $S$. Mutans & $\begin{array}{c}67.3 \\
(53.7-78.4)\end{array}$ & $\begin{array}{c}2.12 \\
(1.47-2.76)\end{array}$ & $\begin{array}{c}74.0 \\
(60.4-84.1)\end{array}$ & $\begin{array}{c}3.08 \\
(2.22-3.94)\end{array}$ & $\begin{array}{c}70.6 \\
(61.1-78.5)\end{array}$ & $\begin{array}{c}2.59 \\
(2.05-3.12)\end{array}$ \\
\hline Only S. Sobrinus & $\begin{array}{c}50.0 \\
(9.45-90.5)\end{array}$ & $\begin{array}{c}1.01 \\
(0-12.7)\end{array}$ & $\begin{array}{c}60.0 \\
(23.1-88.2)\end{array}$ & $\begin{array}{c}2.20 \\
(0-5.41)\end{array}$ & $\begin{array}{c}57.1 \\
(25.0-84.2)\end{array}$ & $\begin{array}{c}1.86 \\
(0-3.95)\end{array}$ \\
\hline $\begin{array}{c}\text { S. Mutans-S. Sobrinus } \\
\text { association }\end{array}$ & $\begin{array}{c}45.5 \\
(33.0-58.5)\end{array}$ & $\begin{array}{c}0.88 \\
(0.52-1.23)\end{array}$ & $\begin{array}{c}71.4 \\
(50.1-86.2)\end{array}$ & $\begin{array}{c}3.71 \\
(2.02-5.41)\end{array}$ & $\begin{array}{c}52.6 \\
(41.5-63.4)\end{array}$ & $\begin{array}{c}1.67 \\
(1.08-2.28)\end{array}$ \\
\hline
\end{tabular}

DMFT; decay, missing and filling permanent teeth.

$* \mathrm{p}<0.05$ using ANOVA for comparison of means and the chi-square test for comparison of proportions between the four groups.

Table 3. Relation between DMFT score $(\leq 3$ or $>3)$ and Streptococcus carrier status group.

\begin{tabular}{|c|c|c|c|c|c|c|}
\hline \multirow{3}{*}{$\begin{array}{l}\text { Streptococcus carrier } \\
\text { status group }\end{array}$} & \multirow{2}{*}{\multicolumn{2}{|c|}{$\begin{array}{c}\begin{array}{c}\text { Age } 12 \text { years } \\
\mathbf{N}=303\end{array} \\
\text { DMFT score* }\end{array}$}} & \multirow{2}{*}{\multicolumn{2}{|c|}{$\begin{array}{c}\begin{array}{c}\text { Age } 15 \text { years } \\
\text { N=311 }\end{array} \\
\text { DMFT score* }\end{array}$}} & \multirow{2}{*}{\multicolumn{2}{|c|}{$\begin{array}{c}\begin{array}{c}\text { Both groups } \\
\text { N=614 }\end{array} \\
\text { DMFT score* } \\
\end{array}$}} \\
\hline & & & & & & \\
\hline & $\begin{array}{c}\leq 3 \\
N=274 \% \\
(95 \% \mathrm{CI})\end{array}$ & $\begin{array}{c}>3 \\
N=29 \% \\
(95 \% \mathrm{CI})\end{array}$ & $\begin{array}{c}\leq 3 \\
N=249 \% \\
(95 \% \text { CI })\end{array}$ & $\begin{array}{c}>3 \\
N=62 \% \\
(95 \% \mathrm{CI})\end{array}$ & $\begin{array}{c}\leq 3 \\
N=523 \% \\
(95 \% \text { CI })\end{array}$ & $\begin{array}{c}>3 \\
\mathrm{~N}=91 \% \\
(95 \% \mathrm{CI})\end{array}$ \\
\hline $\begin{array}{c}\text { Free of Streptococci } \\
\text { Mutans and Sobrinus }\end{array}$ & $\begin{array}{c}65.3 \\
(59.5-70.7)\end{array}$ & $\begin{array}{c}51.7 \\
(34.4-68.6)\end{array}$ & $\begin{array}{c}81.1 \\
(75.8-85.4)\end{array}$ & $\begin{array}{c}53.2 \\
(40.9-65.1)\end{array}$ & $\begin{array}{c}72.8 \\
(68.8-76.4)\end{array}$ & $\begin{array}{c}52.7 \\
(42.5-62.6)\end{array}$ \\
\hline Only S. Mutans & $\begin{array}{c}15.0 \\
(11.2-19.6)\end{array}$ & $\begin{array}{c}37.9 \\
(22.6-55.9)\end{array}$ & $\begin{array}{c}13.3 \\
(9.59-18.0)\end{array}$ & $\begin{array}{c}27.4 \\
(17.8-39.5)\end{array}$ & $\begin{array}{c}14.1 \\
(11.4-17.3)\end{array}$ & $\begin{array}{c}30.8 \\
(22.2-40.8)\end{array}$ \\
\hline Only S. Sobrinus & $\begin{array}{c}0.7 \\
(0.20-2,62)\end{array}$ & - & $\begin{array}{c}1.2 \\
(0.41-3.48)\end{array}$ & $\begin{array}{c}3.2 \\
(0.88-11.0)\end{array}$ & $\begin{array}{c}1.0 \\
(0.41-2.22)\end{array}$ & $\begin{array}{c}2.2 \\
(0.61-7.66)\end{array}$ \\
\hline $\begin{array}{c}\text { S. Mutans-S. Sobrinus } \\
\text { association }\end{array}$ & $\begin{array}{c}19.0 \\
(14.7-24.0)\end{array}$ & $\begin{array}{c}10.3 \\
(3.5-26.3)\end{array}$ & $\begin{array}{c}44.0 \\
(2.48-7.73)\end{array}$ & $\begin{array}{c}16.1 \\
(9.01-27.2)\end{array}$ & $\begin{array}{c}12.0 \\
(9.52-15.1)\end{array}$ & $\begin{array}{c}14.3 \\
(8.54-22.9)\end{array}$ \\
\hline
\end{tabular}

$* \mathrm{p}<0.05$ using the chi-square test for comparison of proportions between the four groups. 
Table 4. Multiple logistic regression analysis with caries prevalence (DMFT $>0$ ) as the dependent variable $(\mathrm{n}=614)$.

\begin{tabular}{|l|c|c|c|}
\hline Independent variables & $\begin{array}{c}\text { Prevalence } \\
\text { Odds Ratio } \\
\text { Exp(B) }\end{array}$ & $\begin{array}{c}\mathbf{9 5 \%} \text { CI } \\
\text { Exp(B) }\end{array}$ & $\begin{array}{c}\text { Wald } \\
\text { p-value }\end{array}$ \\
\hline $\begin{array}{l}\text { Free of Streptococci } \\
\text { (Indicator) }\end{array}$ & 1 & - & - \\
\hline Only S. Mutans* & 3.3 & $2.1-5.5$ & 0.00 \\
\hline Only S. Sobrinus & 2.0 & $0.4-9.1$ & 0.37 \\
\hline S. Mutans-S. Sobrinus Association & 1.5 & $0.9-2.7$ & 0.12 \\
\hline High Intake of cariogenic foods* & 2.1 & $1.3-3.5$ & 0.00 \\
\hline Inappropriate daily tooth brushing & 1.0 & $0.7-1.6$ & 0.98 \\
\hline Low fluoride rinsing & 1.1 & $0.7-1.8$ & 0.66 \\
\hline Age (yrs)* & 1.2 & $1.0-1.3$ & 0.02 \\
\hline
\end{tabular}

* Significant variables, $\mathrm{p}<0.05$.

\section{Discussion}

The aetiology of caries is multifactorial in character, comprising genetic, behavioural, environmental and microbial factors (15). Caries is a polymicrobial infection (16). Every bacterial species plays a role in determining the cariogenicity of the biofilm or dental plaque. In this study we analyzed samples of unstimulated saliva to determine the presence of $S$. mutans and S. sobrinus and to relate it to the presence or absence of caries in schoolchildren in the Valencian Community.

The system we employed to detect $S$. mutans in samples of unstimulated saliva by means of a polymerase chain reaction (qRT-PCR) has been used in other studies and has shown itself to be valid and reliable (14), although the limitations of cross-sectional studies for establishing associations between microorganisms and dental caries should not be forgotten (17).

Determination of $S$. mutans and $S$. sobrinus $\mathrm{CFU} / \mathrm{ml}$ levels by real-time quantitative PCR has been shown to be a reliable, fast method that is applicable in epidemiological studies $(4,9)$.

S. mutans and $S$. sobrinus are the species that have been most frequently isolated from the human oral cavity and have been implicated as the main germs causing dental caries in humans (18).

Numerous studies have shown that the presence of S. sobrinus is associated with greater caries activity (19). $S$. mutans is the predominant species and is sometimes the only one isolated. In the present study, as in other (20), when S. sobrinus was isolated S. mutans was almost always found to be present as well.
The results of this study show $S$. mutans prevalences of $36 \%$ at age 12 and $24.5 \%$ at age $15, S$. sobrinus prevalences of $18.9 \%$ and $8.4 \%$ and $S$. mutans-S. sobrinus association prevalences of $18.2 \%$ and $6.8 \%$ respectively. These figures are well below those obtained in other studies, which range from $51 \%$ to $100 \%$ for S. mutans and from $23 \%$ to $83 \%$ for S. sobrinus $(2-3,21-23)$.

There are several possible explanations for our low prevalence of Streptococcus mutans and S. sobrinus. Firstly, the published epidemiological studies with determinations in saliva of $S$. mutans and $S$. sobrinus by qPCR technologies, are based on a low number of samples, ranging from 80 (4) to 140 samples (11), compared to 614 samples in the present study.

Another important point is that the child population of the region of Valencia, where the random representative sample was obtained, is characterized by low levels of caries, access to public fissure sealant programmes, school-based fluoride mouth-rinsing and a high percentage of tooth brushing, which could influence the low prevalence.

A last point that should be considered when evaluating the data is that our study was based on captured rather than stimulated saliva, and it could be that stimulating the saliva with paraffin, a procedure used in other studies, disturbs the bacterial biofilm that adheres to the enamel surface, leading to a greater number of bacteria being found in the saliva. Although collecting the saliva samples from the tongue might bias the results, there are studies that have found a relationship between the quantities of $S$. mutans in plaque and saliva, so if a large number of germs are found in the saliva, the number in 
the plaque will also be high (24-25). As regards the relationship between $S$. mutans and dental caries, we found significantly higher caries prevalence in the $S$. mutans carriers among both groups of children. We also found a positive relationship between $S$. mutans prevalence and the DMFT index, as did other (26).

With regard to the $S$. mutans- $S$. sobrinus association, in the present study the 15-year-old children with this association exhibited higher DMFT counts, similar to reports in other studies which show that the association of these two bacteria is related to higher caries levels (2-4).

However, the present study did not find this association either in the 12 year-old group or on analyzing the sample as a whole. Longitudinal studies indicate that children harbouring both $S$. mutans and $S$. sobrinus have a significantly higher incidence of dental caries than those who are positive for S. mutans alone (3).

In order to establish the relationship between caries and the presence of certain bacteria, it should be borne in mind that caries lesions pass through various stages according to their depth and that this will influence the presence and predominance of certain microorganisms and the decrease or absence of others (27).

A systematic review of the literature (28) confirms that $S$. mutans plays an important role in the initiation of dental caries of the enamel and root. Nevertheless, some recent studies indicate that the relation between S. mutans and caries is not absolute: high proportions of $S$. mutans can persist on tooth surfaces without injury occurring and caries can develop in the absence of this species (29).

Caries occurs as a result of a complex interaction between dental plaque (whose physiological characteristics may be modified by carbohydrates in the diet), the diet, and oral hygiene practices. These interactions are difficult to understand, especially as our knowledge of the microflora associated with health, disease and the transition from health to disease is very limited (30). In a multiple logistic regression analysis with caries prevalence as the dependent variable, carrying $S$. mutans only, intake of cariogenic foods and age have proved to be significant independent variables.

Our results might suggest a clear association between caries and the presence of Streptococccus mutans but do not confirm such a relationship between caries and the $S$. mutans-S. sobrinus association. In populations with low caries levels, the prevalence of $S$. mutans and S. sobrinus in unstimulated saliva is not as high as might be expected. Their determination in epidemiological studies can provide valuable information for caries risk assessment, although the multifactorial nature of this disease should not be forgotten.

\section{References}

1. van Houte J. Role of micro-organisms in caries etiology. J Dent Res. 1994;73:672-81.

2. Okada M, Soda Y, Hayashi F, Doi T, Suzuki J, Miura K, et al.
PCR detection of Streptococcus mutans and S. sobrinus in dental plaque samples from Japanese pre-school children. J Med Microbiol. 2002;51:443-7.

3. Okada M, Soda Y, Hayashi F, Doi T, Suzuki J, Miura K, et al. Longitudinal study of dental caries incidence associated with Streptococcus mutans and Streptococcus sobrinus in pre-school children. J Med Microbiol. 2005;54:661-5.

4. Loyola-Rodriguez JP, Martinez-Martinez RE, Flores-Ferreira BI, Pati-o-Marín N, Alpuche-Solís AG, Reyes-Macías JF. Distribution of Streptococcus mutans and Streptococcus sobrinus in saliva of Mexican preschool caries-free and caries-active children by microbial and molecular (PCR) assays. J Clin Pediatr Dent. 2008;32:121-6.

5. Hirose H, Hirose K, Isogai E, Miura H, Ueda I. Close association between Streptococcus sobrinus in the saliva of young children and smooth-surface caries increment. Caries Res. 1993;27:292-7.

6. Whiley RA, Beighton D. Current classification of the oral streptococci. Oral Microbiol Immunol.1998;13:195-216.

7. Igarashi T, Yamamoto A, Goto N. Direct detection of Streptococcus mutans in human dental plaque by polymerase chain reaction. Oral Microbiol Immunol. 1996;11:294-8.

8. Shiroza T, Shinozaki N, Watanabe T, Ikemi T, Fukushima K, Abiko Y. Rapid isolation of chromosomal DNA from oral streptococci and polymerase chain reaction-oriented restriction fragmentlength polymorphism analysis for genetic heterogeneity. Oral Microbiol Immunol. 1998;13:11-16.

9. Oho T, Yamashita Y, Shimazaki Y, Kushiyama M, Koga T. Simple and rapid detection of Streptococcus mutans and Streptococcus sobrinus in human saliva by polymerase chain reaction. Oral Microbiol Immunol. 2000;15:258-62.

10. Rupf S, Merte K, Eschrich K. Quantitative determination of Streptococcus mutans by using competitive polymerase chain reaction. Eur J Oral Sci. 1999;107:75-81.

11. Nurelhuda NM, Al-Haroni M, Trovik TA, Bakken V. Caries Experience and Quantification of Streptococcus mutans and Streptococcus Sobrinus in Saliva of Sudanese Schoolchildren. Caries Res. 2010;44:402-7.

12. Almerich-Silla JM, Montiel-Company JM. Oral health survey of the child population in the Valencia Region of Spain (2004). Med Oral Patol Oral Cir Bucal. 2006;11:E369-81.

13. World Health Organization. Oral health surveys: basic methods, 4th edn. Geneva: WHO.1997.

14. Yoshida A, Suzuki N, Nakano Y, Kawada M, Oho T, Koga, T. Development of a 5'nuclease-based real-time PCR assay for quantitative detection of cariogenic dental pathogens Streptococcus mutans and Streptococcus sobrinus. J Clin Microbiol. 2003;41:4438-41.

15. Corby PM, Lyons-Weiler J, Bretz WA, Hart TC, Aas JA, Boumenna T, et al. Microbial Risk Indicators of Early Childhood Caries. J Clin Microbiol. 2005;43:5753-9.

16. Marchant S, Brailsford SR, Twomey AC, Roberts GJ, Beighton D. The predominant microflora of nursing caries lesions. Caries Res 2001;35:397-06.

17. Gabris K, Nagy G, Madléna M, Dénes ZS, Márton S, Keszthelyi $\mathrm{G}$, et al. Association between microbiological and salivary caries activity test and caries experience in Hungarian adolescents. Caries Res. 1999;33:191-5.

18. Babaahmady KG, Challacombe SJ, Marsh PD, Newman HN. Ecological study of Streptococcus mutans, Streptococcus sobrinus and Lactobacillus spp at sub-sites from approximal dental plaque from children. Caries Res. 1998;32:51-8.

19. de Soet JJ, van Loveren C, Lammens AJ, Pavicic MJ, Homburg $\mathrm{CH}$, ten Cate JM, et al. Differences in cariogenicity between fresh isolates of Streptococcus sobrinus and Streptococcus mutans. Caries Res.1991;25:116-22.

20. Rosenbloom RG, Tinanoff N. Salivary Streptococcus mutans levels in patients before, during, and after orthodontic treatment. Am J Orthod Dentofacial Orthop. 1991;100:35-7.

21. Igarashi T, Yamamoto A, Goto N. PCR for detection and identification of Streptococcus sobrinus. J. Med.Microbiol. 2000;49:1069-74.

22. Rodis OM, Shimono T, Matsumura S, Hatomoto K, Matsuo K, 
Kariya N. et al. Cariogenic bacteria and caries risk in elderly Japanese aged 80 and older with at least 20 teeth. J Am Geriatr Soc. 2006;54:1573-7.

23. Eun-Jung C, Sung-Hoon L. Young-Jae K. Quantitative real-time polymerase chain reaction for Streptococcus Mutans and Streptococcus Sobrinus in dental plaque samples and its association with early childhood caries. Int J Paediatric Dent. 2009;19:141-7.

24. Mundorff SA, Eisenberg A D, Leverett D H, Espeland MA, Proskin HM. Correlation between numbers of microflora in plaque and saliva. Caries Res. 1990;24:312-7.

25. Sullivan A, Borgström MK, Granath L, Nilsson G. Number of mutans streptococci or lactobacilli in a total dental plaque sample does not explain the variation in caries better than the numbers in stimulated saliva. Community Dent Oral Epidemiol. 1996;24:159-63.

26. Hegde PP, Ashok Kumar BR, Ankola VA. Dental caries experience and salivary levels of Streptococcus mutans and Lactobacilli in 13-15 years old children of Belgaum city, Karnataka. J Indian Soc Pedo Prev Dent. 2005;23:23-6.

27. Scheie AA, Petersen FC. The biofilm concept: consequences for future prophylaxis of oral diseases? Crit Rev Oral Biol Med. 2004;15:4-12.

28. Tanzer JM, Livingston J, Thompson AM. The microbiology of primary dental caries in humans. J Dent Educ. 2001;65:1028-37.

29. Takahashi N, Nyvad B. Caries Ecology Revisited: Microbial Dynamics and the Caries Process. Caries Res. 2008; 42:409-18.

30. Beighton D. the complex microflora of high-risk individuals and group and its role in the caries process. Community Dent Oral Epidemiol. 2005;33:248-55.

\section{Acknowledgments}

This work was supported by the Ministry of Education of the Regional Government of Valencia, project GVPR/2008/383 (principal researcher José María Montiel Company). Mary Georgina Hardinge provided translation assistance. 